\title{
Efficacy of Bio-agents and Botanical Extracts against Tikka Leaf Spot of Groundnut (Arachis hypogaea L) Waldron and J Kohler
}

\author{
Jalde Ravi Kumar* and Sunil Zacharia \\ Department of Plant Pathology, Sam Higginbottom University of Agriculture, Technology and \\ Sciences, Prayagraj (U.P.), India \\ *Corresponding author
}

\section{A B S T R A C T}

Keywords

Bio-agent,

Botanicals,

Groundnut, Seed

treatment, Tikka

disease

Article Info

Accepted:

22 April 2021

Available Online:

10 May 2021
The experiment was conducted at the research plot of the Department of Plant Pathology, SHUATS, Prayagraj, U.P. during the kharif season of 2019-2020with RBD having nine treatments replicated thrice to evaluate the efficacy of some botanical extract and bio agents for the management of groundnut tikka leaf spot disease. Fungicides and bio agent used for seed treatment were Trichoderma viride@5\% and mancozeb (check)@4g/kg, as foliar spray wereNeem leaf extract @20\% Datura leaf extract@20\%Tulasi leaf extract@20\%Onion bulb@ 20\%Debdaru leaf extract@20\%Garlic clove@20\% and Moncozeb@2g/lit. The treatments were applied thrice as spray at 30,45 and 60 DAS. Trichoderma viride (S.T.) and Neem leaf extract (F.S.) were the most effective treatment to manage the tikka leaf spot disease, germination percentage, plant height, no.of leaves, and yield of groundnut (t/ha).

\section{Introduction}

Groundnut (Arachis hypogaea L.) is one of the world's most important oilseed crops (Dwivedi et al., 2003), ranking the 13th most important food crop and 4th most important oilseed crop of the world (Surendranatha et al., 2011), being cultivated in more than 100 countries in six continents (Sharma and Mathur, 2006). India is one of the largest producers of oilseeds in the world and occupies an important position in the Indian agricultural economy. Groundnut is called as the 'King' of oilseeds. It is one of the most important food and cash crops of our country.
Groundnut is also called as wonder nut and poor men's cashew nut. It contains $48-50 \%$ of oil and 26-28\% of protein, and is a rich source of dietary fiber, minerals, and vitamins.

In India, groundnut production in Kharif (2019-20) was 63.11 lakh tonnes (Agricultural Market Intelligence Centre, PJTSAU 2020). National Agricultural Cooperative Marketing Federation of India (NAFED) is holding a 2018 crop peanut stock of around 0.26 million tonnes as on 22nd 2019. NAFED bought 0.71 million tonnes of peanut during 2018-19 from farmers at government fixed MSP of Rs. 4890 per 
quintal (NAFED 2019-2020).

Groundnut leaf spot is most common in which early leaf-spots (ELS) Cercospora arachidicola and late leaf-spot (LLS) Cercospora personatum is mainly prevalent during the kharif than the rabi season. The spots begin to appear on one to two months old plants. ELS are sub-circular to irregular, 1 to $10 \mathrm{~mm}$ in diameter. Lesions are commonly dark (reddish) brown to black on the upper surface and light brown on the lower leaf surface. Leaf spot on upper surface is commonly surrounded by a yellow chlorotic halo. LLS are usually smaller and more nearly circular than early leaf spot lesions, 1 to $6 \mathrm{~mm}$ in diameter and are commonly dark gray or black on the lower leaf surface. There is no yellow halo around them. The LLS is usually more severe than ELS (Sharma, 2006) late leaf spot caused by Cercosporidium personatum is the destructive foliar disease in groundnut. The most obvious effect of this disease is the loss of photosynthetic tissue, which leads to premature defoliation. Late leaf spot is almost co-existent with the crop and contributes to significant loss in yield throughout the world (Meena, 2010).

\section{Materials and Methods}

\section{In vitro experiment}

Different media employed for growth of Cercospora arachidicola Potato dextroseagar, Potato sucrose agar, Richards synthetic agar, Czapex dox agar, Carrot dextrose agar, Sabouraud's agar and Oat meal agar.

\section{Field experiment}

Study on the "Efficacy of bio-agents and botanical extracts against Tikka leaf spot of groundnut (Arachis hypogaea L)" was conducted during kharif 2019, at central research farm, Sam Higginbottom University of Agriculture, Technology and Sciences Prayagraj. There are six treatments including an untreated control and application of foliar sprays was given in the Randomized Block Design.Neem leaf extract (Azadirachta indica) @ 20\% Foliar spray, Datura leaf extract (Datura metel) @ 20\% Foliar spray, Tulasi leaf extract (Ocimum sanctum) @ 20\%Foliar spray, Onion bulb (Allium cepa) @ $20 \%$ Foliar spray, Debdaru leaf extract (Polyalthia longifolia) @ 20\%Foliar spray, Garlic clove (Allium sativam) @ 20\% Foliar spray, Mancozeb @75\%WP 2g/lit foilar spray and Seed treatment(treated check) and Trichodermaviride@5\% (S.T).

The selected fresh leaves of healthy plants were collected and washed thoroughly with clean water and dried to drain the water. About $10 \mathrm{~g}$ of plant leaves were grounded using pestle and mortar by adding same proportion $(10 \mathrm{ml})$ of sterilised distilled water in weight by volume method. The botanical extract thus obtained by grounding was filtered through muslin cloth and the extract was diluted by adding sterilised distilled water to get required concentration. The mancozeb was weighed $2 \mathrm{gm}$ with the help of weighing machine and mixed thoroughly with 1 lit. Control was maintained without any treatment.

\section{Results and Discussion}

\section{Radial Growth of Cercospora arachidicola on different media}

In the present study table 1 and plate 1 shows that growth of has recorded. The maximum radial growth of Cercospora arachidicola was observed on Potato sucrose agar $(85 \mathrm{~mm})$, Richards agar $(83 \mathrm{~mm})$, Czapeks dox agar $(79 \mathrm{~mm})$, Oatmeal agar $(77 \mathrm{~mm})$, Carrot dextrose agar $(65 \mathrm{~mm})$, Potato dextrose agar (45mm) followed by, Sabourauds`s agar( $39 \mathrm{~mm})$. Similar finding have been 
reported by Surendra et al., (2015); Poornima and Yashoda (2014) and Swamy (2012).

\section{Effect of bio-agents and botanical extracts on seed germination of Groundnut at 15DAS}

The result presented in table 2 and depicted in figure 1 revealed that all the treatments were statistically significant as compared to control. At 60 DAS, among the bio-agents and botanicals used the Maximum Per cent seed germination was recorded in $\mathrm{T}_{8}$ Trichoderma viride $5 \%$ (94.287\%), $\mathrm{T}_{1}$ - Neem leaf extract@ 20\% (93.253\%), T $\mathrm{T}_{3}$ - Tulasi leaf extract @ 20\% (85.273\%), T 6 - Garlic leaf extract@20\% (91\%), T4 - Onion bulb@ 20\% (88.853\%), $\mathrm{T}_{2}$ - Datura leaf extract @ $20 \%(86.753 \%)$ followed by, $\mathrm{T}_{5}$ - dabdaru leaf extract @ 20\% (90.447\%), minimum Per cent disease intensity was shown in $\mathrm{T}_{0}$ control $(83.433 \%)$ and the plants treated with $\mathrm{T}_{7}$ Mancozeb @ 2 gm/lit showed Maximum Per cent seed germination (95.287\%) as check control. Similar finding have been reported by Hasan et al., (2016) and Mushrif et al., (2017).

Table.1 Radial Growth of Cercospora arachidicola on different media

\begin{tabular}{|l|c|}
\hline Media & Radial growth of Cercospora arachidicola $(\mathbf{m m})$ \\
\hline Potato sucrose agar & 85.000 \\
\hline Richards agar & 83.000 \\
\hline Czapeks dox agar & 79.000 \\
\hline Oatmeal agar & 77.000 \\
\hline Carrot dextrose agar & 65.000 \\
\hline Potato dextrose agar & 45.000 \\
\hline Sabourauds`s agar & 39.000 \\
\hline SE(d) & 0.816 \\
\hline C.D.(0.05) & 1.768 \\
\hline
\end{tabular}

Table.2 Effect of bio-agents and botanical extracts on seed germination (\%) of groundnut at 15 DAS

\begin{tabular}{|l|l|c|}
\hline Symbols & Treatment & Germination \% \\
\cline { 3 - 3 } & & 15 DAS \\
\hline $\mathbf{T}_{\mathbf{1}}$ & Neem leaf extract @ 20\% (F.S.) & 93.253 \\
\hline $\mathbf{T}_{\mathbf{2}}$ & Datura leaf extract @ 20\%(F.S.) & 86.753 \\
\hline $\mathbf{T}_{\mathbf{3}}$ & Tulasi leaf extract @ 20\% (F.S.) & 85.273 \\
\hline $\mathbf{T}_{\mathbf{4}}$ & Onion bulb@ 20\% (F.S.) & 88.853 \\
\hline $\mathbf{T}_{\mathbf{5}}$ & Debdaru leaf extract @ 20\% (F.S.) & 90.447 \\
\hline $\mathbf{T}_{\mathbf{6}}$ & Garlic clove @ 20\% (F.S.) & 91.000 \\
\hline $\mathbf{T}_{\mathbf{7}}$ & Mancozeb @ 75\%WP 2g/lit(F.S.) and (S.T.) (check) & 95.287 \\
\hline $\mathbf{T}_{\mathbf{8}}$ & Trichoderma viride@ 5\% Seed treatment & 94.287 \\
\hline $\mathbf{T}_{\mathbf{0}}$ & Control & 83.433 \\
\hline & S.Ed( \pm ) & 1.408 \\
\hline & C.D. $(0.05)$ & 2.991 \\
\hline
\end{tabular}


Table.3 Effect of bio-agents and botanical extracts on plant disease intensity of tikka leaf spot of groundnutat 60 DAS

\begin{tabular}{|l|l|c|c|c|}
\hline Symbols & Treatment & PDI & \\
\hline & & 30DAS & 45DAS & 60 DAS \\
\hline $\mathbf{T}_{\mathbf{1}}$ & Neem leaf extract @ 20\% (F.S.) & 2.718 & 7.161 & 13.621 \\
\hline $\mathbf{T}_{\mathbf{2}}$ & Datura leaf extract @ 20\%(F.S.) & 3.932 & 11.571 & 18.459 \\
\hline $\mathbf{T}_{\mathbf{3}}$ & Tulasi leaf extract @ 20\% (F.S.) & 3.561 & 8.369 & 14.521 \\
\hline $\mathbf{T}_{\mathbf{4}}$ & Onion bulb@ 20\% (F.S.) & 3.687 & 10.726 & 16.390 \\
\hline $\mathbf{T}_{\mathbf{5}}$ & Debdaru leaf extract @ 20\% (F.S.) & 4.069 & 12.635 & 20.553 \\
\hline $\mathbf{T}_{\mathbf{6}}$ & Garlic clove @ 20\% (F.S.) & 3.566 & 9.469 & 15.402 \\
\hline $\mathbf{T}_{\mathbf{7}}$ & Mancozeb @ 75\%WP 2g/lit(F.S.) and (S.T.) (check) & 2.615 & 5.369 & 9.707 \\
\hline $\mathbf{T}_{\mathbf{8}}$ & Trichoderma viride@ 5\% Seedtreatment & 2.701 & 6.671 & 10.479 \\
\hline $\mathbf{T}_{\mathbf{0}}$ & Control & 5.997 & 15.579 & 27.287 \\
\hline & S.Ed( \pm ) & 0.371 & 0.256 & 0.176 \\
\hline & C.D.(0.05) & 0.786 & 0.542 & 0.373 \\
\hline
\end{tabular}

Table.4 Effect of bio-agents and botanical extracts on plant height $(\mathrm{cm})$ of groundnut at 60 DAS

\begin{tabular}{|l|l|c|c|c|}
\hline \multirow{2}{*}{ Symbols } & \multicolumn{3}{c|}{ Treatments } & \multicolumn{3}{c|}{ Plant height (cm) } \\
\cline { 3 - 5 } & & 30 DAS & 45 DAS & 60 DAS \\
\hline $\mathbf{T}_{\mathbf{1}}$ & Neem leaf extract @ 20\% (F.S.) & 20.007 & 36.047 & 48.040 \\
\hline $\mathbf{T}_{\mathbf{2}}$ & Datura leaf extract @ 20\%(F.S.) & 16.047 & 31.127 & 42.060 \\
\hline $\mathbf{T}_{\mathbf{3}}$ & Tulasi leaf extract @ 20\% (F.S.) & 18.560 & 34.447 & 47.227 \\
\hline $\mathbf{T}_{\mathbf{4}}$ & Onion bulb @ 20\% (F.S.) & 17.337 & 33.060 & 46.660 \\
\hline $\mathbf{T}_{\mathbf{5}}$ & Debdaru leaf extract @ 20\% (F.S.) & 16.613 & 31.440 & 43.293 \\
\hline $\mathbf{T}_{\mathbf{6}}$ & Garlic clove @ 20\% (F.S.) & 18.180 & 33.713 & 46.980 \\
\hline $\mathbf{T}_{\mathbf{7}}$ & Mancozeb @ 75\%WP 2g/lit(F.S.) and (S.T.) (check) & 22.060 & 39.020 & 52.847 \\
\hline $\mathbf{T}_{\mathbf{8}}$ & Trichoderma viride@ @\% Seed treatment & 20.173 & 36.120 & 48.820 \\
\hline $\mathbf{T}_{\mathbf{0}}$ & Control & 15.680 & 28.533 & 38.047 \\
\hline & S.Ed( \pm ) & 1.344 & 0.975 & 1.659 \\
\hline & C.D.(0.05) & 2.849 & 2.087 & 3.517 \\
\hline
\end{tabular}

Table.5 Effect of bio-agents and botanical extracts on number of leaves of groundnut at 60 DAS

\begin{tabular}{|l|l|c|c|c|}
\hline \multirow{2}{*}{ Symbols } & \multicolumn{1}{|c|}{ Treatment } & \multicolumn{3}{c|}{ No.ofLeaves } \\
\cline { 3 - 5 } & & 30 DAS & 45 DAS & 60 DAS \\
\hline $\mathbf{T}_{\mathbf{1}}$ & Neem leaf extract @ 20\% (F.S.) & 46.000 & 99.333 & 176.400 \\
\hline $\mathbf{T}_{\mathbf{2}}$ & Datura leaf extract @ 20\%(F.S.) & 36.067 & 84.200 & 166.600 \\
\hline $\mathbf{T}_{\mathbf{3}}$ & Tulasi leaf extract @ 20\% (F.S.) & 42.467 & 97.267 & 175.333 \\
\hline $\mathbf{T}_{\mathbf{4}}$ & Onion bulb@ 20\% (F.S.) & 40.000 & 88.133 & 170.600 \\
\hline $\mathbf{T}_{\mathbf{5}}$ & Debdaru leaf extract @ 20\% (F.S.) & 44.200 & 97.867 & 176.000 \\
\hline $\mathbf{T}_{\mathbf{6}}$ & Garlic clove @ 20\% (F.S.) & 38.267 & 86.200 & 168.600 \\
\hline $\mathbf{T}_{\mathbf{7}}$ & Mancozeb @ 75\%WP 2g/lit(F.S.) and (S.T.) (check) & 52.067 & 113.400 & 183.533 \\
\hline $\mathbf{T}_{\mathbf{8}}$ & Trichoderma viride@ @\% Seed treatment & 49.400 & 100.267 & 179.733 \\
\hline $\mathbf{T}_{\mathbf{0}}$ & Control & 31.000 & 81.800 & 160.867 \\
\hline & S.Ed( \pm ) & 1.828 & 2.465 & 2.067 \\
\hline & C.D. $(0.05)$ & 3.876 & 5.177 & 4.383 \\
\hline
\end{tabular}


Table.6 Effect of bio-agents and botanical extracts on yield of groundnut at 120 DAS

\begin{tabular}{|l|l|c|}
\hline Symbols & Treatment & Yield (t/ha) \\
\hline & & 120 DAS \\
\hline $\mathbf{T}_{\mathbf{1}}$ & Neem leaf extract @ 20\% (F.S.) & 1.660 \\
\hline $\mathbf{T}_{\mathbf{2}}$ & Datura leaf extract @ 20\%(F.S.) & 1.278 \\
\hline $\mathbf{T}_{\mathbf{3}}$ & Tulasi leaf extract @ 20\% (F.S.) & 1.539 \\
\hline $\mathbf{T}_{\mathbf{4}}$ & Onion bulb@ 20\% (F.S.) & 1.412 \\
\hline $\mathbf{T}_{\mathbf{5}}$ & Debdaru leaf extract @ 20\% (F.S.) & 1.388 \\
\hline $\mathbf{T}_{\mathbf{6}}$ & Garlic clove @ 20\% (F.S.) & 1.497 \\
\hline $\mathbf{T}_{\mathbf{7}}$ & Mancozeb @ 75\%WP 2g/lit(F.S.) and (S.T.) (check) & 1.775 \\
\hline $\mathbf{T}_{\mathbf{8}}$ & Trichoderma viride@ 5\% Seed treatment & 1.673 \\
\hline $\mathbf{T}_{\mathbf{0}}$ & Control & 0.833 \\
\hline & S.Ed \pm () & 0.139 \\
\hline & C.D. $(0.05)$ & 0.296 \\
\hline
\end{tabular}

Fig.1 Effect of bio-agents and botanical extracts on seed germination of groundnut at 15 DAS

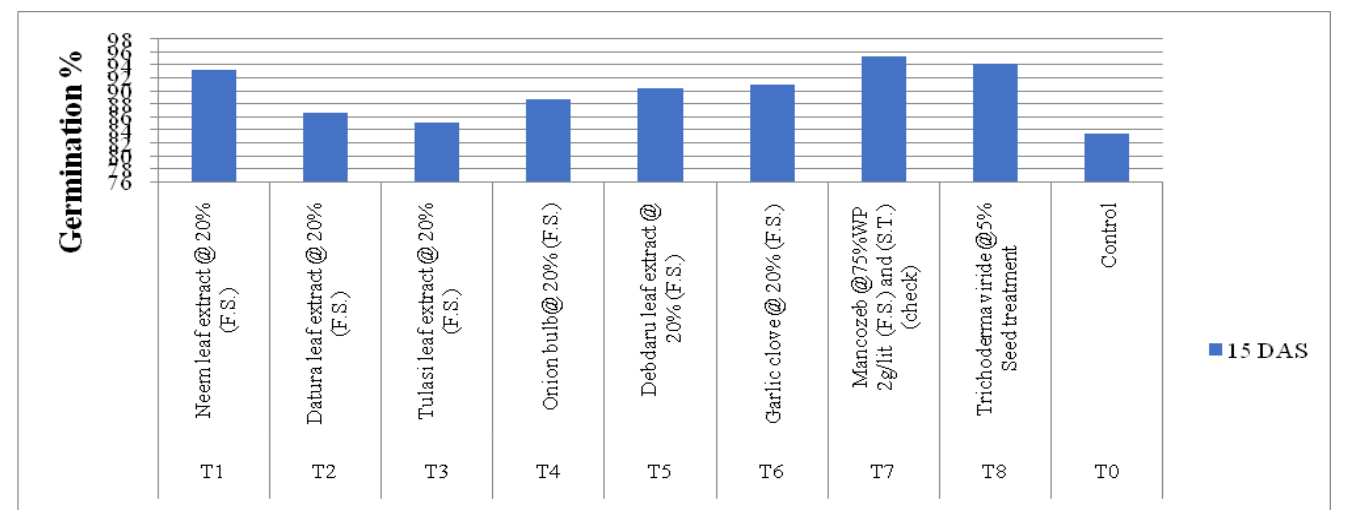

Fig.2 Effect of bio-agents and botanical extracts on plant disease intensity of tikka leaf spot of groundnutat $60 \mathrm{DAS}$

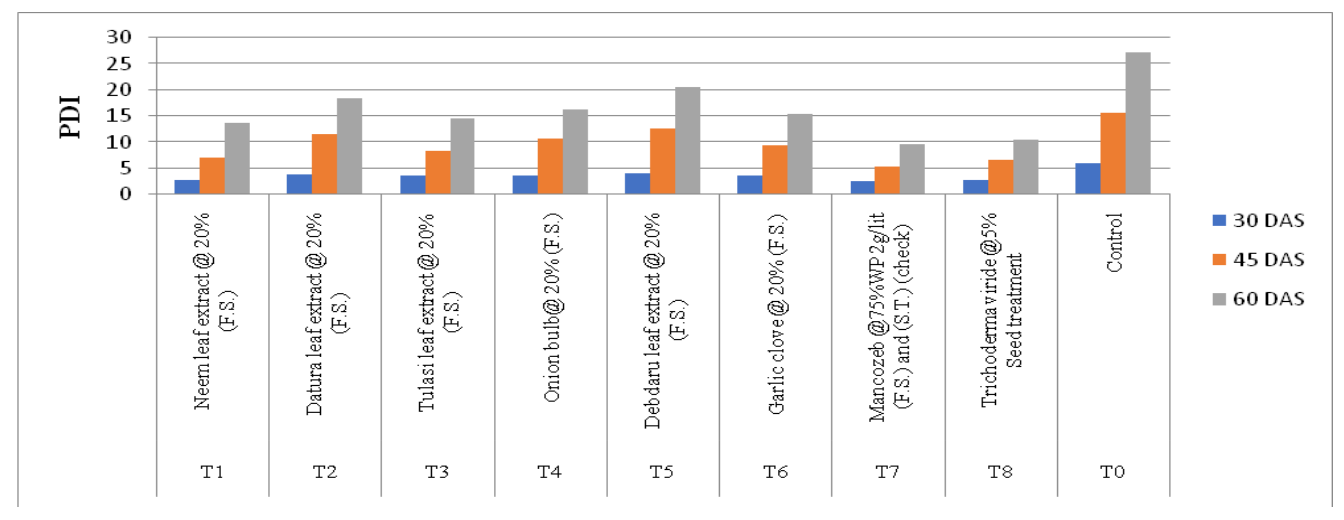


Fig.3 Effect of bio-agents and botanical extracts on plant height $(\mathrm{cm})$ of groundnut at 60 DAS

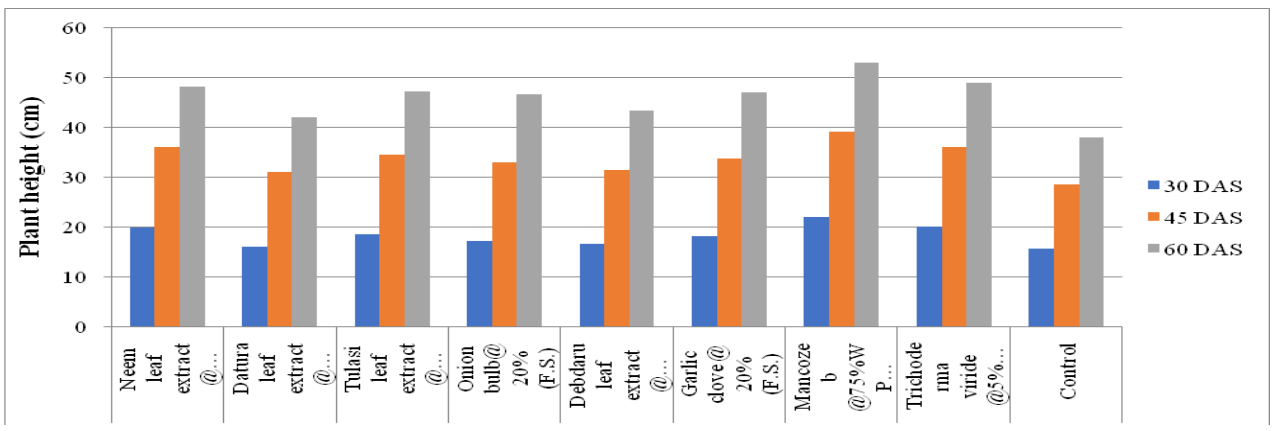

Fig.4 Effect of bio-agents and botanical extracts on Number of leaves of groundnut at 60 DAS

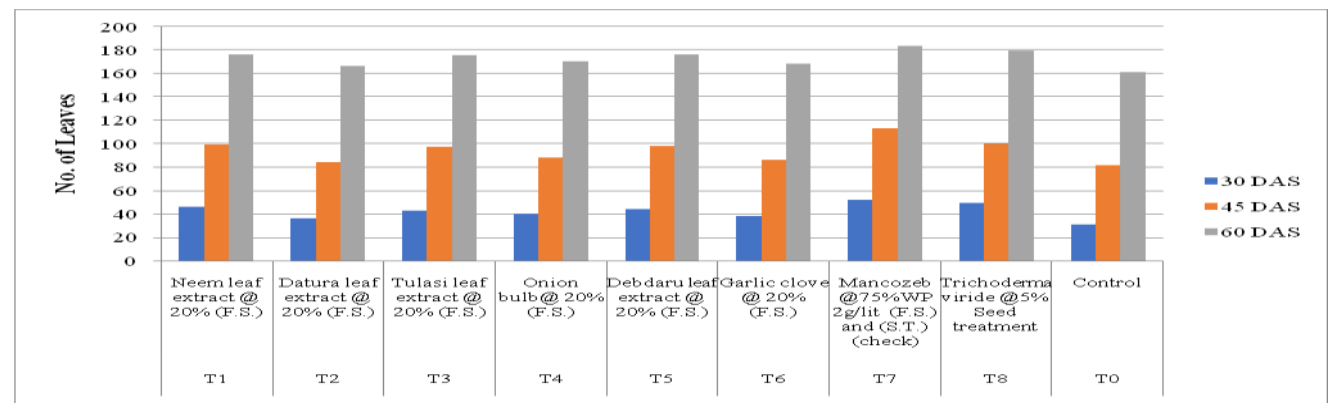

Fig.5 Effect of bio-agents and botanical extracts on yield of groundnut at 120 DAS



Plate.1 Growth of Cercospora arachidicola on different solid media

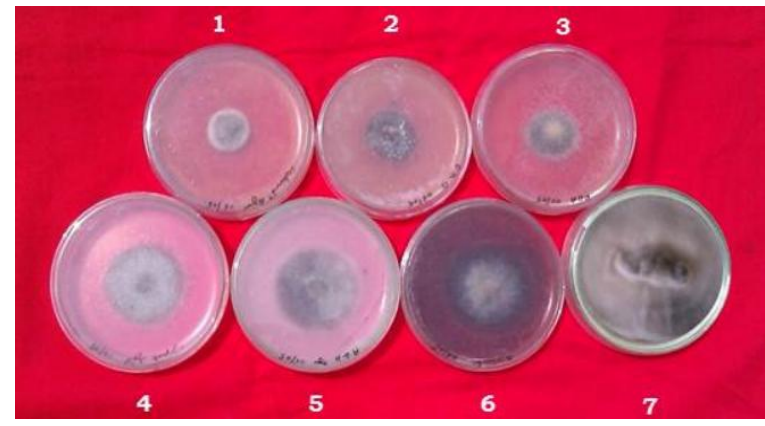

1. Sabouraud's agar

2. Oat meal agar

3. Potato dextrose agar

4. Czapek's agar

5. Carrot dextrose agar 
Effect of bio-agents and botanical extracts on plant disease intensity oftikka leaf spot of groundnutat $60 \mathrm{DAS}$

The result presented in table 3 and depicted in figure 2 revealed that all the treatments were statistically significant as compared to control. At 60 DAS, among the bio-agents and botanicals used the minimum Per cent disease intensity was recorded in $\mathrm{T}_{8}$ Trichoderma viride $5 \%(10.479 \%), \mathrm{T}_{1}$-Neem leaf extract@ 20\% (13.621\%), $\mathrm{T}_{3}$ - Tulasi leaf extract@20\%(14.521\%), T6 - Garlic leaf extract@20\% (15.402\%), $\mathrm{T}_{4}$ - Onion bulb@ 20\% (16.390\%), $\mathrm{T}_{2}$ - Datura leaf extract @ $20 \%(18.459 \%)$ followed by, $\mathrm{T}_{5}-$ dabdaru leaf extract @ 20\% (20.553\%), Maximum Per cent disease intensity was shown in $\mathrm{T}_{0}$ control (27.287\%) and the plants treated with $\mathrm{T}_{7}$ Mancozeb @ 2 gm/lit showed minimum Per cent disease intensity (9.707.\%) as check control. Similar results have been obtained by Kishore et al., (2001), Ihejirika et al., (2010).

\section{Effect of bio-agents and botanical extracts} on plant height $(\mathrm{cm})$ of groundnut at 60 DAS

The result presented in table 4 and depicted in figure 3 revealed that all the treatments were statistically significant as compared to control. At 60 DAS, among the bio-agents and botanicals used the maximum plant height was recorded in $\mathrm{T}_{8}$-Trichoderma viride $5 \%(48.820 \mathrm{~cm}), \mathrm{T}_{1}$-Neem leaf extract @2 0\% (48.040cm), $\mathrm{T}_{3}$-Tulasi leaf extract @ 20\% $(47.227 \mathrm{~cm}), \mathrm{T}_{6}$-Garlic leaf extract @ 20\% (46.980cm), $\mathrm{T}_{4}$-Onion bulb @ 20\% $(46.660 \mathrm{~cm}), \mathrm{T}_{2}$-Datura leaf extract @ 20\% $(42.060 \mathrm{~cm})$ followed by, $\mathrm{T}_{5}$-dabdaru leaf extract@ 20\% (43.293cm), minimum plant height was shown in $\mathrm{T}_{0}-$ control $(38.047 \mathrm{~cm})$ and the plants treated with $\mathrm{T}_{7}$ Mancozeb @ 2 $\mathrm{gm} /$ lit showed maximum plant height $(52.847 \mathrm{~cm})$ as check control. Similar finding have been reported by Hossain and Hossain
(2013), Uddin et al., (2013) and Ramesh and Zacharia (2017).

Effect of bio-agents and botanical extracts on Number of leaves of Groundnut at 60 DAS

The result presented in table 5 and depicted in figure 4 revealed that all the treatments were statistically significant as compared to control. At 60 DAS, among the bio-agents and botanicals used the maximum no. of leaves was recorded in $\mathrm{T}_{8}$ - Trichoderma viride $5 \%$ (179.733), $\mathrm{T}_{1}$ - Neem leaf extract @ 20\%(176.400), $\mathrm{T}_{3}$ - Tulasi leaf extract @ 20\% (175.533), $\mathrm{T}_{6}$ - Garlic leaf extract @ 20\% (168.600), $\mathrm{T}_{4}$ - Onion bulb @ 20\% (170.600), $\mathrm{T}_{2}$ - Datura leaf extract @2 0\% (166.600) followed by, $\mathrm{T}_{5}$ - dabdaru leaf extract @ 20\% (176.000), minimum no. of leaves was shown in $\mathrm{T}_{0}$ - control (160.867) and the plants treated with $\mathrm{T}_{7}$ Mancozeb @ $2 \mathrm{gm} /$ lit showed maximum no.of leaves (183.533) as check control. Similar finding have been reported by Tiwari et al., (2004) and Hossain and Hossain (2013) to best control of tikka diseases and increased the no. of leaves.

\section{Effect of bio-agents and botanical extracts} on yield of Groundnut at 120DAS

The result presented in table 6 and figure 5 revealed that all the treatments were statistically significant as compared to control. At 120 DAS, among the bio-agents and botanicals used the maximum yield was recorded in $\mathrm{T}_{8}$-Trichoderma viride $5 \%$ (1.673t/ha), $\mathrm{T}_{1}$-Neem leaf extract @ 20\% (1.660t/ha), T3-Tulasi leaf extract @ 20\% (1.539t/ha), $\mathrm{T}_{6}$-Garlic leaf extract @ 20\% (1.497t/ha), $\mathrm{T}_{4}$-Onion bulb @ 20\% (1.412t/ha), T 2 -Datura leaf extract @ 20\% $(1.278 \mathrm{t} / \mathrm{ha})$ followed by, $\mathrm{T}_{5}$-dabdaru leaf extract@20\% (1.388t/ha), minimum yield was shown in $\mathrm{T}_{0}-$ control $(0.833 \%)$ and the plants treated with $\mathrm{T}_{7}$ Mancozeb @ 2 gm/lit 
showed maximum yield (1.775t/ha) as check control. Similar results were found by Hossain and Hossain (2013) and Mane (2012).

In the present investigation on the "Efficacy of bio-agents and botanical extracts against Tikka leaf spot of groundnut (Arachis hypogaea L)" Trichoderma viride was found best treatment to manage for leaf spot (Cercospora arachidicola) of Groundnut. From cost benefit ratio Trichoderma viride treatment were statisticlly found as most economic method over control after chemical treatment. Yield obtained from plot as well as Trichoderma viride treated plot were comparable to that of chemical treated one. Since chemicals have many harmful effects on the environment as well as the human health, botanicals and bio-agents would be considered as better as it is eco-friendly also.

\section{Acknowledgement}

The Head sincerely desires to express his heartfelt respect, deep sense of gratitude toDepartment of Plant Pathology, SHUATS, Naini agricultural institute, Prayagraj(U.P.) India for providing all necessary facilities for carrying out the research work.

\section{References}

Agricultural Market Intelligence Centre PJTSAU (2020). Source: Www.agricoop.com

Dwivedi, S. L., Crouch, J. H. Nigam, S. N. Ferguson, M. E. and Paterson, A. H. (2003). Molecular breeding of groundnut for enhanced productivity and food security in the semiarid tropics Opportunities and challenges. Advanced Agronomy 80:153-221.

Hasan M.M., Hossain I., M.A. Kashem, M.M.A. Mondal , M.Y. Rafii and M.A. Latif (2016). Effect of botanicals and
Bio fungicide on controlling tikka disease (Cercospor sp.) of groundnut (Arachis hypogea L.) Legume Research, 39(1):114-122, Agricultural Research Communication Centre www.arccjournals.com/www.legumeres earch.in

Hossain.M. H. and Hossain.I. (2013). Screening of different plant extracts against leaf spot(Cercospora arachidicola and Cercosporidium personatum) of groundnut (Arachishypogaea L.)Bangladesh Journal of Agricultural Research 38(3): 491-503.

Hossain, M.H. and Hossain I. (2013). Invitro studies of some selected botanicals and Baubiofungicide on mycelial growth and conidial germination of Cercospora arachidicola and Cercosporidium personatum. International Journal of Agricultureal Research Innovation and Technology 3(2):36-40.

Ihejirika, G. O., Nwufo, M. I., Obiefuna, J.C. and Ibeawuchi, I. I. (2004).Evaluation of some fungal diseases and yield of groundnut in groundnut-based cropping systems. Archives of Phytopathology and Plant Protection. 43 (11): 10441049.

Kishore, Krishna, G., Pande, S. and. Narayana, J. Rao. (2001). Control of Late Leaf Spot of Groundnut (Arachis hypogaea) by Extracts from Non-Host Plant Species. Journal of Plant Pathology. 17 (5): 264-27.

Mane(2012). Management of tikka disease of groundnut by using different botanicals and bioagents International Journal of Plant Protection 5(2):308-311.

Meena (2010). Survival and effect of Pseudomonas fluorescens formulation developed with various carrier materials in the management of late leaf spot of groundnut, International Journal Plant 
Protection 3(2):200-202.

Mushrif S. K., M. J. Manju, T. H. Shankarappaland Nagaraju (2017) .Comparative Efficacy of fungicides against tikka disease of groundnut caused by Cercospora arachidicola and Cercosporidium personatum quarterly theecoscan 11(1\&2): 67-71, 2017.www.theecoscan.com

Poornima and Yashoda Hegde (2014). Cultural characterstics of Cercospora beticola sacc. causing leaf spot of palak ,International Journal of Plant Protection 07(2):441-443.

Ramesh Mapari Amol and Sunil Zacharia (2017) .Efficacy of Bio-agents and Botanicalsagainst leaf Spot (Cercospora rachidicola Hori) of Groundnut (Arachis hypogaea L.) Journal of Pharmacognosy and Phytochemistry 2017, 6(5):504-506.

Sharma (2006). PD. Plant Pathology. Narosa Publishing House Pvt. Ltd. New Delhi, 178-179.

Sharma, K. K. and Mathur, B. P. (2006). Peanut (Arachis hypogaea L.). Methods in Molecular Biology 343:347-358.

Surendra, Sunil Zacharia, Ramana Reddy, Eswara Reddy and P.Chowdappa (2015). Effect of different media on growth and sporulation of Cercospora arachidicola causing early leaf spot of ground nut, An International Quarterly Journal of Life Sciences 10(4): 18251828.

Surendranatha, E. C., Sudhakar, C. and Eswara, N. P. (2011). Aflatoxin contamination in groundnut induced by Aspergillus flavus type fungi, International Journal of Applied Biology and Pharmaceutical Technology 2: 2-9.

Swamy K.M., M.K. Naik, S. Patil, and Y.S.Amaresh. (2012). Growth of Cercospora capsici on different solid and liquid media Journal of Mycopathological Research 50(2):313316.

Tiwari, R. K. S., Ojha, B. M. and Chandravanshi S. S.(2004).Efficacy of fungicides in controlling leaf spots (Cercospora arachidicola and Cercosporidium personatum) and rust (Puccinia arachidis) in groundnut. Journal of Mycoogy and Plant Pathology. 34 (2): 520-521.

Uddin.M.N., M.A. Bakr, M.R. Islam, M.I. Hossain and A Hossain(2013). Bioefficacy of plant extracts to control Cercospora leaf spot of mungbean (Vigna radiata), International Journal of Agricultural Reserach Innovation and Technology 3(1): 60-65.

\section{How to cite this article:}

Jalde Ravi Kumar and Sunil Zacharia. 2021. Efficacy of Bio-agents and Botanical Extracts against Tikka Leaf Spot of Groundnut (Arachis hypogaea L) Waldron and J Kohler. Int.J.Curr.Microbiol.App.Sci. 10(05): 744-752. doi: https://doi.org/10.20546/ijcmas.2021.1005.084 